\title{
AN ANALYSIS OF GOVERNMENTAL POLICIES IN MANAGING COVID-19 PANDEMIC: COMPARATIVE STUDY BETWEEN INDONESIA AND VIETNAM, PERIOD OF JANUARY - MARCH 2020
}

\author{
Salsabila, Inge Dhamanti \\ Faculty of Public Health Universitas Airlangga, Jl. Dr.Ir.H.Soekarno, Mulyorejo, Surabaya, East Java 60115, \\ Indonesia
}

\begin{abstract}
Since WHO declared COVID-19 as a global pandemic, COVID-19 management has become a problem for countries with limited resources and weak health systems. The purpose of this article is to describe the implementation of policies in Indonesia and Vietnam, in which both countries have limited resources in facing the COVID-19 pandemic. The present study is a narrative review which compares he COVID-19 policies in two countries. The study is conducted by searching relevant literature on Google Scholar with the keywords "Penerapan Kebijakan COVID-19 di Indonesia", "COVID-19 policy responses in Vietnam", "lesson from limited resource country to control COVID-19", and also scrutinizing the official website managed by the Indonesian Ministry of Health and the Vietnam Ministry of Health. The inclusion criteria are open access papers published between December 2019 and March 2020 in the form of original articles and review articles. This study found the differences in policy implementation between Indonesia and Vietnam in terms of the number of policies, implementation time, scope, and the basis for making policy decisions. Unlike Indonesia, the implementation of policies carried out in Vietnam is more anticipatory, based on previous experience in dealing with the SARS epidemic in 2003. In dealing with the COVID-19 pandemic, as a country with limited resources in the health system, it is very important to implement policies that are more preventive and anticipatory based on past experience in dealing with pandemics.
\end{abstract}

Keywords: country comparison, COVID-19, pandemic, policy responses

\begin{abstract}
ABSTRAK
Sejak ditetapkan oleh WHO sebagai pandemi global, manajemen penanganan COVID-19 menjadi tantangan tersendiri bagi negara yang memiliki keterbatasan sumberdaya maupun sistem pelayanan kesehatannya. Penulisan artikel ini bertujuan untuk menggambarkan penerapan kebijakan di Indonesia dan Vietnam sebagai negara yang memiliki keterbatasan sumberdaya maupun sistem pelayanan kesehatannya dalam menghadapi pandemi global COVID-19. Metode penulisan artikel ini adalah narrative review. Kami melakukan pencarian literatur yang relevan pada Google Scholar dengan kata kunci "Penerapan Kebijakan COVID-19 di Indonesia", "COVID-19 Policy Responses in Vietnam", "Lesson from Limited Resource Country to control COVID-19", serta website resmi yang dikelola oleh Kementerian Kesehatan Indonesia dan Kementerian Kesehatan Vietnam. Kriteria inklusi yang digunakan adalah open access article yang dipublikasi sejak Desember 2019 hingga Maret 2020 dalam bentuk original article maupun review article. Penelitian ini menemukan adanya perbedaan penerapan kebijakan di Indonesia dan Vietnam pada jumlah kebijakan, waktu penerapan, ruang lingkup, dan dasar dalam pengambilan keputusan kebijakan tersebut. Berbeda dengan Indonesia, penerapan kebijakan yang dilakukan di Vietnam lebih bersifat antisipatif yang didasarkan pada pengalaman sebelumnya dalam menghadapi epidemic SARS tahun 2003. Sebagai negara yang memiliki keterbatasan sumberdaya dan sistem pelayanan kesehatannya dalam menghadapi pandemi COVID-19 sangat penting untuk menerapkan kebijakan yang lebih bersifat preventif dan antisipatif yang didasarkan pada pengalaman dalam menghadapi pandemi sebelumnya.
\end{abstract}

Kata Kunci: perbandingan negara, COVID-19, pandemi, respon kebijakan

Correspondece Address: Salsabila, Faculty of Public Health Universitas Airlangga, Jl. Dr.Ir.H.Soekarno, Mulyorejo, Surabaya, East Java60115, Indonesia,E-mail: s.a.l.s.a.b.i.l.a-2017@fkm.unair.ac.id 


\section{Introduction}

In this period of the pandemic all countries in the world are required to be able to adapt by implementing various efforts and policies in dealing with the impact of a new type of disease caused by the coronavirus disease 2019 (COVID-19) or Sars-CoV-2. COVID-19 is a new disease that has a relatively fast transmission rate and high risk of death. ${ }^{1}$ The transmission of this virus is mainly through direct contact or consumption of natural Sars-CoV-2 hosts such as bats and intermediate hosts such as pangolin, snake, rats, and others. ${ }^{2}$ However, recent studies indicate that bats as natural hosts for COVID-19 are able to infect human cells without the need for an intermediate reservoir. Transmission of this disease can occur from person to person, especially among family members and friends who are in close contact with a person with COVID-19 or someone who is infected with COVID-19 but does not show symptoms. ${ }^{3}$

Sars-CoV-2 or COVID-19 was first detected in the city of Wuhan, Hubei Province, China, which was later declared as global pandemic by the World Health Organization (WHO) on the eleventh of March 2020 after spreading widely to 114 countries all over the world. ${ }^{4}$ Over the past 20 years, several countries in the world have had experience in dealing with global pandemics caused by viral infections such as HIV, Influenza A virus subtype H1N1 (A/H1N1), Influenza A virus subtype H5N1 (A/H5N1), Sars-CoV-1, Mers-CoV, and Ebola. ${ }^{5}$ However, by the latest discovery of a new type of virus called COVID-19 or Sars-CoV-2 with an extremely rapid spread rate, many countries in the world do not have adequate preparations in managing the pandemic. Until now, a definitive therapy to cure the virus is still yet to be found. ${ }^{6}$ Since research on vaccines and drugs for COVID-19 is still ongoing, strategic efforts from each country are needed to anticipate and prevent the continuous transmission of the virus between humans.

Indonesia and Vietnam are two developing countries in the Southeast Asia region that have been affected by the COVID-19 pandemic. Due to its geographical position in the same land as China, Vietnam has a higher risk of being badly affected by COVID-19. Therefore, Vietnam has made long-term planning efforts as a form of prevention since the very early discovery of this virus. $^{7}$ Vietnam is considered as the first country to confirm two positive cases of COVID-19 on the twenty third of January 2020. Meanwhile, Indonesia, which is quite distant from China, confirmed the first positive case of COVID-19 on the second of March, 2020 with the discovery of two cases. ${ }^{8}$ Ever since the confirmation of COVID-19 positive cases in the two countries, the lifethreatening COVID-19 pandemic has continued to spread to all regions in Indonesia and Vietnam.

Below we compare these two countries because both of these countries have GDP growth rates of over 5\%, the Human Development Index (HDI) scores of Indonesia (0.71) and Vietnam $(0.70)$ were all considered to have a 'medium-high' human development level. ${ }^{9} \mathrm{HDI}$ is a composite 
measure of education, the standard of living, length, and quality of life. Indonesia and Vietnam have radically decentralized their health-care systems with the devolution of health services to local government. The restructuring has affected the implementation of systems performance and equity. Furthermore, the Universal Health Coverage (UHC) in Indonesia and Vietnam both are operating in a single-payer system, and also the health expenditure in Indonesia and Vietnam are lower than other countries in South East Asia. ${ }^{10}$ Other than that, as a developing country with limited resources and lack resilient health system, it is indeed challenging for both Indonesia and Vietnam to deal with the COVID-19 pandemic. The ratio of the number of health workers to the people in Indonesia and Vietnam is $0.4 \%$ and $0.8 \%$ per 1,000 people. ${ }^{11}$ Despite these limited health resources, Vietnam is proven to be able to manage the COVID-19 pandemic well by successfully reducing the number of confirmed cases of COVID-19 to zero for 10 consecutive days and as many as 2 cases of death due to COVID-19 until July 2020. ${ }^{12}$ Meanwhile, Indonesia's COVID-19 cases have not decreased since the first cases were discovered and have reached 5,131 deaths due to COVID-19 until July 2020. ${ }^{8}$ The great gap in conditions between the two countries becomes an interesting discussion. The study focuses on finding differences in terms of policies implemented by Indonesia and Vietnam in dealing with the COVID-19 pandemic.

COVID-19 is a global pandemic that certainly raises concerns for various groups, especially among the community. The public concern will continue to grow up as the number of positive cases and deaths from COVID-19 increases in a relatively short time. The ability of each country to adapt to the existing situation through the implementation of effective and anticipatory policies is the initial foundation that must be done in order to be able to successfully overcome the COVID-19 pandemic. Decision making on anticipatory policies related to efforts in preventing the spread of COVID-19, management of infected patients, protection of health workers, and the control of public concern must be considered thoughtfully. This article aims to describe the differences in the implementation of policies carried out by Indonesia and Vietnam as developing countries that have limited resources and health care systems in facing the global COVID-19 pandemic. By identifying the differences, it may provide overview and insights for other countries having the same background in handling the COVID-19 pandemic.

\section{Method}

The article was constructed by using a non-systematic review method (narrative review). The Data collection process was carried out through obtaining articles that are relevant to the research objectives through the medium of Google Scholar. The keywords used include "Penerapan Kebijakan COVID-19 di Indonesia" or implementation of COVID-19 policies in Indonesia, "COVID-19 policy responses in Vietnam", and "lesson from limited country resource to control COVID-19". Furthermore is a selection process that carried out by selecting articles which 
appropriate for the objectives and criteria inclusion of the research. In addition, the author also scrutinized the official website managed by the Indonesian Ministry of Health and the Vietnam Ministry of Health. The inclusion criteria in the search for this article are open access articles in the form of original articles and review articles published from December 2019 to March 2020, available in the full text both in English or Indonesian. After the searching process, 114 articles were excluded and 7 articles which appropriate for the objectives of the study are selected. In addition the official website was managed by the Ministry of Health, which were then analyzed by making comparisons between both countries Indonesia and Vietnam. The results of this nonsystematic review analysis were described in the form of a comparison table. Result synthesis was done by comparing policies related to the number of policies, implementation time, scope, and basis for policy decisions making. The author used the time period as a framework in the comparative analysis described in Table 1.

\section{Results}

From the study on the implementation of policies carried out in Indonesia and Vietnam in overcoming COVID-19, the author found that there are differences in terms of the number and timing of policy implementation which are presented in the following comparison table. . $^{5,13,14,15,16}$ The findings in Table 1 show the policies taken by the government in both countries from January to March 2020. Those policies which are compared in the following table are the national policies that have been determined by the central government and the national health ministry in both countries. $5,4,7,13,14,15,16$ Policies discussed include health policies, cross-border policies, mobility policies, conducting quarantine, and other national policies in dealing with the COVID-19 pandemic. 
Table 1. Differences in the Implementation of Policies in Indonesia and Vietnam in Managing COVID-19 Pandemic from January to March 2020

\begin{tabular}{|c|c|c|}
\hline \multirow{2}{*}{ Time Period } & \multicolumn{2}{|c|}{ Policy Implementation } \\
\hline & Vietnam & Indonesia \\
\hline Discovery of first case & 23 January 2020 & 2 March 2020 \\
\hline January 2020 & $\begin{array}{l}\text { a. Conducted Risk Assessment of 2019-nCoV } \\
\text { (COVID-19). } \\
\text { b. Established National Steering Committee } \\
\text { chaired by the Deputy Prime Minister. } \\
\text { c. Issued national response plan in January. } \\
\text { d. Suspension of all cross-border flights and } \\
\text { arrivals to and from China. } \\
\text { e. Repatriation of Vietnamese citizens from } \\
\text { China. } \\
\text { f. Vietnam's Ministry of Health has issued an } \\
\text { instruction on tightening the quarantine and } \\
\text { surveillance at the Vietnam-China border. } \\
\text { g. The Public Health Emergency Operation } \\
\text { Center under the direction of the Ministry of } \\
\text { National Health stressed the importance of } \\
\text { preventing and detecting disease as early as } \\
\text { possible to the local hospitals and health } \\
\text { offices. } \\
\text { h. Vietnam's Ministry of National Health issued } \\
\text { guidelines and plans to prevent the spread of } \\
\text { the COVID-19 virus. }\end{array}$ & $\begin{array}{l}\text { a. Banned all travel activities from Hubei } \\
\text { Province, China, the global epicenter of } \\
\text { COVID-19. } \\
\text { b. Repatriation Of Indonesian citizens who } \\
\text { are in Hubei Province, China. }\end{array}$ \\
\hline February 2020 & $\begin{array}{l}\text { a. Provided adequate health service spots } \\
\text { (hospitals) for patients with COVID-19 and } \\
\text { quarantine areas for people considered as } \\
\text { suspects. } \\
\text { b. Suspension of all cross-border flights and } \\
\text { arrivals to and from China. } \\
\text { c. Performed strict supervision, prevention and } \\
\text { control over the transportation of goods from } \\
\text { Chinese borders. } \\
\text { d. Issued guidelines for the implementation of } \\
\text { surveillance, prevention and supervision of } \\
\text { COVID-19. } \\
\text { e. Issued guidelines for home quarantine, } \\
\text { centralized quarantine, and diagnosis and } \\
\text { treatment for COVID-19. } \\
\text { f. Performed strict inspection towards } \\
\text { passengers from China at airports, seaports } \\
\text { and land crossings. } \\
\text { g. Implemented quarantine, case management, } \\
\text { prevention, and control within the community. } \\
\text { h. Imposed local lockdown in the northern region } \\
\text { of Vinh Puc Province, the area where the most } \\
\text { Covid-19 infections spread in Vietnam, for } 20 \\
\text { days. }\end{array}$ & $\begin{array}{l}\text { a. The Ministry of National Health } \\
\text { declared responsive actions against } \\
\text { Novel 2019-nCoV (COVID-19) as a } \\
\text { disease that could cause an outbreak. } \\
\text { b. Indonesia National Agency for Disaster } \\
\text { Countermeasure (BNPB) declared a } \\
\text { special emergency situation for COVID- } \\
19 \text { epidemic disaster. }\end{array}$ \\
\hline
\end{tabular}


Table 2. Differences in the Implementation of Policies in Indonesia and Vietnam in Managing COVID-19 Pandemic from January to March 2020

\begin{tabular}{|c|c|c|}
\hline \multirow{2}{*}{ Time Period } & \multicolumn{2}{|c|}{ Policy Implementation } \\
\hline & Vietnam & Indonesia \\
\hline February 2020 & $\begin{array}{l}\text { a. Closed all educational activities and banned } \\
\text { all activities involving a large number of } \\
\text { people. } \\
\text { b. Issued a policy of revoking the business } \\
\text { permit for pharmacies and drugstores that } \\
\text { increased the price of medical devices. }\end{array}$ & 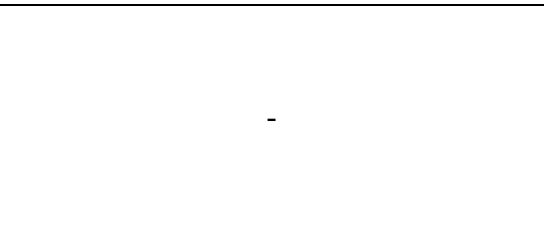 \\
\hline March 2020 & $\begin{array}{l}\text { a. Suspended all travel activities from China, } \\
\text { Korea, Iran and Italy. } \\
\text { b. Suspended the entry of foreigners into } \\
\text { Vietnam. } \\
\text { c. Extended the period of closing for schools } \\
\text { and other educational activities. } \\
\text { d. Prohibited the procurement of religious } \\
\text { activities or other public activities involving a } \\
\text { large number of people. } \\
\text { e. Conducted intensive surveillance and isolation } \\
\text { or self-quarantine. } \\
\text { f. Performed case management by tracing } \\
\text { newcomers and those who had direct contact } \\
\text { with patients up to three clusters. } \\
\text { g. Encouraged people who are indicated as } \\
\text { suspect to perform self-quarantine and } \\
\text { isolation, banned travel activities, and } \\
\text { reinforced "15-day national social distancing". }\end{array}$ & $\begin{array}{l}\text { a. Formed Task Force for the acceleration } \\
\text { COVID-19 management. } \\
\text { b. Distribution of special grant allocation } \\
\text { for health service infrastructure in } \\
\text { response to the handling of COVID- } \\
19 \text { cases. } \\
\text { c. Established laboratory network for } \\
\text { research regarding COVID-19. } \\
\text { d. Banned social gathering and group } \\
\text { activities both in the public and local } \\
\text { environment. } \\
\text { e. Established referral hospitals } \\
\text { specifically designated for COVID-19 } \\
\text { patients. } \\
\text { f. Implemented early detection means of } \\
\text { COVID-19 cases through the provision } \\
\text { of extensive rapid tests for Indonesian } \\
\text { citizens. } \\
\text { g. Issued Medical Guidelines for Quick } \\
\text { Response and Public Health Aspects of } \\
\text { COVID-19 in Indonesia. } \\
\text { h. Refocused activities, fiscal allocations, } \\
\text { and procurement of goods and services } \\
\text { to accelerate the handling of COVID- } \\
19 \text {. } \\
\text { i. Increased the socialization of COVID- } \\
19 \text { prevention to all levels of } \\
\text { community. } \\
\text { j. Imposed large-scale social restrictions } \\
\text { (PSBB) to all regions in Indonesia to } \\
\text { suppress the spread of virus. }\end{array}$ \\
\hline
\end{tabular}

\section{Discussion}

In terms of economic status based on Gross National Income (GNI) per Capita of countries in ASEAN in March 2020, Indonesia and Vietnam are both labelled as middle-income countries with Indonesia being slightly on the higher rank. ${ }^{17}$ The Southeast Asia Global Health Security Index 2019 shows that Indonesia is in fourth place and Vietnam is in fifth. ${ }^{18}$ Even though Vietnam is one level below Indonesia in terms of Global Health Security Index, Vietnam is considered more well-prepared in handling the pandemic as its geographic condition is closer to China, which is the source of COVID-19 transmission. Vietnam has been internationally acknowledged for formulating low-cost, highly-effective policy implementation in the early phases of the COVID-19 pandemic. ${ }^{14}$ The Vietnamese government had been acted very quickly even before COVID-19 was declared as a global pandemic by implementing efforts focusing on preventive measures and taking public health 
measures widely. Because of the implementation of this policy, since the end of March 2020, Vietnam has recorded 212 total cases of COVID-19 and zero mortality rate. ${ }^{12}$

When compared with the policies implemented by the Indonesian Ministry of Health when the COVID-19 case has not been found in Indonesia, it is in the total opposite. It can be seen in Table 1 that there has been no response to the implementation of preventive policies in January and February. Before the discovery of positive cases in Indonesia, the number of policies implemented in Indonesia is also very small. The Indonesian government just issued a new more anticipatory policy in March, when the first COVID-19 case was already confirmed on the second of March 2020. This shows that Indonesia is quite late in implementing policies regarding the management of this pandemic. It later results in an uncontrolled outbreak throughout all regions in Indonesia. At the end of March 2020, there are 1528 cases of COVID-19 in Indonesia with 136 deaths. This indicates a huge gap compared to Vietnam and several countries in the Southeast Asia region. ${ }^{8}$

In terms of the scope of policy implementation in Vietnam and Indonesia, both of them are quite broad as they do not only focus on the health aspect. Vietnamese government uses a multisectoral approach in a timely, accurate and transparent manner in overcoming the COVID-19 pandemic. ${ }^{14}$ All of the political systems including local institutions in the health sector, public security forces, army, and local communities take a role in implementing policies regarding the COVID-19 pandemic. The closing of schools and revoking business permits for pharmacies that raise prices for medical devices prove that the policies implemented have covered the sectors of education and economy in Vietnam. It is no different with Indonesia, various sectors have been involved in handling the COVID-19 pandemic. Ministry of Health, Indonesia National Agency for Disaster Countermeasure (BNPB), Ministry of Finance, Indonesian Police (POLRI), Ministry of Communication and Information, as well as Ministry of Villages, Disadvantaged Areas, and Transmigration are all involved in the implementation of policies regarding the COVID-19 pandemic. $^{5}$ The implementation of Large-Scale Social Restrictions (PSBB) is imposed by the government to prevent the virus from widely-spreading by closing schools, universities, and offices so that students and workers keep staying at home. The whole governmental policy in Indonesia covers multi sectoral aspects such as economy and education.

Indonesia is the fourth most populous country in the world. Thus, it can be estimated that the management of the disease will be more difficult and more time consuming than the other countries with lesser numbers of the population. ${ }^{5}$ Therefore, Indonesia needs the right approach in coping with the virus by implementing anticipatory and right-targeted policies. When the outbreak of SARS-CoV2 (COVID-19) reached its peak in China during December 2019 - February 2020, the advent of the virus was still yet to be found in Indonesia. During that period, the government still has not responded to the implementation of preventive and anticipatory policies. On the second of March 2020, after President Joko Widodo officially announced that two positive cases of 
COVID-19 had been confirmed, the government showed various responses and implemented policies in various sectors. ${ }^{19}$ This might lead to the higher number of COVID-19 cases and deaths experienced by Indonesia compared to Vietnam. It is due to the lack of responsiveness and agility of the government in anticipating the further spread of the virus.

Further, Indonesia's health care facility is still seen as unready in facing the coming of the COVID-19 pandemic. The government's agile response upon the readiness of health service facilities should have been performed earlier before the discovery of the COVID-19 case in Indonesia. The delayed reaction could be a contributing factor in the soaring number of deaths due to COVID-19. Distribution of special grant allocation for infrastructure in health services related to COVID-19, the setting up of special referral hospitals for COVID-19, Medical Guidelines for Rapid Response and Public Health Aspects of COVID-19 in Indonesia and other policy responses were running late in March 2020. Based on the latest data from Indonesia's Ministry of Health, there are only 309,100 beds in Indonesia hospitals, with most of them located in Java. Indonesia only has 2.7 ICU beds per 100,000 patients which is the lowest in Asia. ${ }^{20}$ In addition, the limited number of ventilators and uneven distribution of equipment also contribute to the dire problem of health services in Indonesia. Indonesia should have taken the matter seriously and performed well in preparation right after the discovery of COVID-19 case in China. ${ }^{21}$ By means of his research in January 2020, Professor Joseph Wu from China has raised the alarm to the public that 2019-nCoV (COVID-19) will become a global epidemic. In addition, he also suggested that a preventive plan must be carried out by ensuring the availability of drugs, personal protective equipment (PPE), and the resources needed to deal with the global outbreak. ${ }^{22}$

In addition, considering the proximity of its geographic condition to China, Vietnam has a greater possibility of getting the worse effect of the COVID-19 pandemic. ${ }^{16}$ Moreover, it has to be noted that Vietnam's health service system still has limited resources and weaknesses related to insurance and patient welfare. Thus, the responsive and adaptive measures in implementing policies carried out by the Vietnamese government in handling the pandemic deserves a flattering remark. ${ }^{23}$ Vietnamese government seems to have learned from its past experience in dealing with the Severe Acute Respiratory Syndrome (SARS) epidemic in 2003. Vietnam's success in effectively controlling SARS is recorded as the first in the world and it is achieved by carrying out complete isolation of patients and implementing strict control of nosocomial infections from the early stages of the epidemic. Vietnam seriously involves the lesson learned from previous experience in dealing with the COVID-19 pandemic. The lesson learned includes performing early risk management by taking adequate action from the very early stage of the disease. ${ }^{16}$ Vietnam has implemented Risk Assessment of 2019-nCoV, issued a National Response Plan, and implemented other anticipatory policies since early January 2020. The factor behind the success of Vietnam in reducing the number of COVID-19 cases with zero mortality cases due to COVID-19 until the end 
of March 2020 is their ability in taking lessons from previous experiences during the 2003 SARS epidemic and establishing a public health response mechanism that has proven to be effective until now.

The limitation of this study is the lack of prior research on the topic because pandemic COVID-19 was new cases that have not been discovered before. Therefore, there is still little research about policies carried out by a country to overcome this COVID-19 pandemic. Other than that, this study only discusses policies that have been carried out in limitation period of time and countries.

\section{Conclusion}

Ever since the confirmation of COVID-19 as a global pandemic by WHO, all countries in the world have implemented various policies and efforts to be able to overcome this pandemic. Based on the results of this non-systematic review analysis in various literature, there are several differences in policies applied in Indonesia and Vietnam in dealing with the COVID-19 pandemic. The results of the comparison between the policy implementations of the two countries show that the implementation of policies based on the results of early risk management analysis has proven effective in overcoming the COVID-19 pandemic. As a country that has limited resources and quite a weak health service system, the implementation of preventive and anticipatory policies are the key to managing the pandemic. The timing of implementation and the basis for policy making from experience in dealing with previous pandemics are also very essential in handling the COVID-19 pandemic.

It is necessary to conduct further literature review within a longer period of time considering the condition and situation of the COVID-19 pandemic that is constantly changing. The comparison among policy implementations in handling the COVID-19 pandemic can also be carried out in several other countries with the same background. By knowing the differences in the implementation of policies in particular countries, the other countries will be able to gain valuable insights in coping with the COVID-19 pandemic or other similar conditions that may occur in the future.

\section{Acknowledgement}

The author would like to send his gratitude toward Ms. Inge Dhamanti as Lecture at the Department of Health Policy and Administration Faculty of Public Health Universitas Airlangga for the guidance in the arrangement process of this article. 


\section{Funding}

This study and arrangement process of this article were self-funded and not granted by any party.

\section{Conflict of Interest}

The authors of this article declare that they are neither affiliated with any organization nor any financial and non-financial interest in this article.

\section{Reference}

1. Susilo A, Rumende CM, Pitoyo CW, Santoso WD, Yulianti M, Herikurniawan H, et al. Coronavirus Disease 2019: Tinjauan Literatur Terkini. J Penyakit Dalam Indones. 2020;7(1):45.

2. Hoffmann M, Kleine-Weber H, Schroeder S, Krüger N, Herrler T, Erichsen S, et al. SARSCoV-2 Cell Entry Depends on ACE2 and TMPRSS2 and Is Blocked by a Clinically Proven Protease Inhibitor. Cell. 2020;181(2):271-280.e8.

3. Peretto G, Sala S, Caforio ALP. Acute myocardial injury, MINOCA, or myocarditis? Improving characterization of coronavirus-associated myocardial involvement. Eur Heart J. 2020;41(22):2124-5.

4. Harlianty RA, Widyastuti T, Mukhlis H, Susanti S. Study on Awareness of COVID 19, Anxiety, and Complince on Social Distancing in Indonesia During Coronavirus Disease 2019 (COVID 19) Pandemic. Res Sq. 2020;1(1):1-16.

5. Djalante R, Lassa J, Setiamarga D, Sudjatma A, Indrawan M, Haryanto B, et al. Review and analysis of current responses to COVID-19 in Indonesia: Period of January to March 2020. Prog Disaster Sci. 2020;6:100091.

6. Whitworth J. COVID-19: A fast evolving pandemic. Trans R Soc Trop Med Hyg. 2020;114(4):227-8.

7. Van Nguyen H, Van Hoang M, Dao ATM, Nguyen HL, Van Nguyen T, Nguyen PT, et al. An adaptive model of health system organization and responses helped Vietnam to successfully halt the Covid-19 pandemic: What lessons can be learned from a resourceconstrained country. Int J Health Plann Manage. 2020;(May):1-5.

8. Worldometers. Coronavirus Cases and Deaths in Indonesia [Internet]. 2020 [cited 2020 Aug 5]. Available from: https://www.worldometers.info/coronavirus/country/indonesia/

9. United Nations Development Programme. Human Development Report [Internet]. 2020 [cited 2021 Jan 21]. Available from: http://hdr.undp.org/

10. Ng JYS, Ramadani RV, Hendrawan D, Duc DT, Kiet PHT. National Health Insurance Databases in Indonesia, Vietnam and the Philippines. PharmacoEconomics - Open 
[Internet]. 2019;3(4):517-26. Available from: https://doi.org/10.1007/s41669-019-0127-2

11. World Bank. Rasio Dokter per 1.000 Penduduk [Internet]. 2017 [cited 2020 Aug 10]. Available from: https://databoks.katadata.co.id/datapublish/2020/04/02/rasio-dokterindonesia-terendah-kedua-di-asia-tenggara

12. Worldometers. Coronavirus Cases and Deaths in Vietnam [Internet]. 2020 [cited 2020 Aug 5]. Available from: https://www.worldometers.info/coronavirus/country/viet-nam/

13. Ristyawati A. Efektifitas Kebijakan Pembatasan Sosial Berskala Besar Dalam Masa Pandemi Corona Virus 2019 oleh Pemerintah Sesuai Amanat UUD NRI Tahun 1945. Adm Law Gov J [Internet]. 2020;3(2):240-9. Available from: https://ejournal2.undip.ac.id/ index.php/alj/article/view/7989

14. Duong DM, Le VT, Ha BTT. Controlling the COVID-19 Pandemic in Vietnam: Lessons From a Limited Resource Country. Asia-Pacific J Public Heal. 2020;32(4):161-2.

15. Huynh TLD. The COVID-19 containment in Vietnam: What are we doing? J Glob Health. 2020;10(1):10-2.

16. La VP, Pham TH, Ho MT, Nguyen MH, Nguyen KLP, Vuong TT, et al. Policy response, social media and science journalism for the sustainability of the public health system amid the COVID-19 outbreak: The vietnam lessons. Sustain. 2020;12(7).

17. World Bank. Gross National Income (GNI) per Kapita Negara-Negara di Asia Tenggara [Internet]. 2020 [cited 2020 Jul 25]. Available from: https://databoks.katadata.co.id/ datapublish/

18. Nuclear Threat Initiative, Johns Hopkins Center for Health Security TEIU. Indeks Ketahanan Kesehatan Global Asia Tenggara [Internet]. 2019 [cited 2020 Jul 25]. Available from: https://databoks.katadata.co.id/datapublish/2020/01/29/kualitas-kesehatan-indonesiaperingkat-empat-di-asia-tenggara

19. Kementerian Kesehatan Indonesia. Kesiapsiagaan Menghadapi Infeksi COVID-19 [Internet]. 2020 [cited 2020 Aug 5]. Available from: https://www.kemkes.go.id/

20. Phua J, Faruq MO, Kulkarni AP, Redjeki IS, Detleuxay K, Mendsaikhan N, et al. Critical Care Bed Capacity in Asian Countries and Regions. Crit Care Med. 2020;(January):654-62.

21. Horton R. COVID-19 and the NHS -"a national scandal.” Lancet. 2020;395(January).

22. Setiati S, Azwar MK. COVID-19 and Indonesia. Acta Med Indones. 2020;52(1):84-9.

23. Vuong QH. Sociodemographic factors influencing Vietnamese patient satisfaction with healthcare services and some meaningful empirical thresholds. Iran J Public Health. 2018;47(1):119-26. 